\title{
Pengaruh Konsentrasi Ekstrak Kulit Buah Maja (Aegle Marmelos (l.) Corea) terhadap Laju Korosi Baja Karbon API 5L pada Medium NaCl $3 \%$ dan $\mathrm{H}_{2} \mathrm{SO}_{4} 3 \%$
}

\author{
Amilia Rasitiani $^{(1)^{*}}$, Ediman Ginting ${ }^{(1)}$, dan Pulung Karo Karo ${ }^{(1)}$ \\ (1) Jurusan Fisika FMIPA Universitas Lampung \\ Jl.Prof. Dr. Soemantri Brojonegoro No.1 Gedung Meneng Bandar Lampung 35145 \\ *E-mail: amiliarasitiaani@gmail.com,
}

Diterima (24 Januari 2018), direvisi (12 Februari 2018)

\begin{abstract}
A study has been conducted on the extract concentration effect of Maja Peel as an inhibitor of low carbon API 5L in corrosive medium of $\mathrm{NaCl} 3 \%$ and $\mathrm{H}_{2} \mathrm{SO}_{4} 3 \%$. The soaking process of low carbon API 5L was done for 35 days with variation of addition inhibitor concentrations at $0 \%, 0,4 \%, 0,5 \%, 0,6 \%, 0,7 \%$, and $0,8 \%$. The testing of Corrosion rate is done by weight loss method. The results showed that the highest corrosive rate in corrosive medium of $\mathrm{NaCl} 3 \%$ and $\mathrm{H}_{2} \mathrm{SO}_{4} 3 \%$ was at $0 \%$ which is inhibitor concentration, $0,06 \times 10^{4} \mathrm{~mm} / \mathrm{y}$ and $16,55 \times 10^{4} \mathrm{~mm} / \mathrm{yconcentration}$. Meanwhile, the lowest corrosion rate at $0.8 \%$ inhibitor concentration for corrosive medium of NaCl $3 \%$ and $0.5 \%$ for $\mathrm{H}_{2} \mathrm{SO}_{4} 3 \%$ corrosive medium. Hence, the greatest effectiveness of corrosion occurs at the concentration of $0.8 \%$ in a corrosive medium of $\mathrm{NaCl} 3 \%$ with effectiveness of $85,71 \%$ and $0.5 \%$ in corrosive medium of $\mathrm{H}_{2} \mathrm{SO}_{4} 3 \%$ with the effectiveness of $79.35 \%$. The characterization result of X-Ray Diffraction (XRD) shows that the phase formed is pure Fe. Characterization of Scanning Electron Microscopy (SEM) showed uneven clusters and smaller sizes, holes and cracks also with less than $0.8 \%$ inhibitors for corrosive medium of $\mathrm{NaCl} 3 \%$ and $0.5 \%$ for corrosive medium of $\mathrm{H}_{2} \mathrm{SO}_{4} 3 \%$ compared with $0 \%$ inhibitor of maja peel extract on corrosive medium of $\mathrm{NaCl} 3 \%$ and $\mathrm{H}_{2} \mathrm{SO}_{4} 3 \%$. Characterization of Energy Dispersive Spectroscopy (EDS) in samples with corrosive medium of $\mathrm{H}_{2} \mathrm{SO}_{4} 3 \%$ obtained the element $\mathrm{S}$ (Sulfate).
\end{abstract}

Keywords: low carbon API $5 \mathrm{~L}$, the extract of maja peel, corrosion inhibitor, $\mathrm{NaCl}$, and $\mathrm{H}_{2} \mathrm{SO}_{4}$.

Abstrak. Telah dilakukan penelitian mengenai pengaruh konsentrasi ekstrak kulit buah maja sebagai inhibitor pada baja karbon API 5L dalam medium korosif $\mathrm{NaCl} 3 \%$ dan $\mathrm{H}_{2} \mathrm{SO}_{4} 3 \%$. Perendaman baja karbon API 5L dilakukan selama 35 hari dengan variasi konsentrasi penambahan inhibitor ekstrak kulit buah maja $0 \%, 0,4 \%, 0,5 \%, 0,6 \%, 0,7 \%$, dan $0,8 \%$. Pengujian laju korosi dilakukan dengan metode kehilangan berat. Hasil penelitian menunjukkan laju korosi terbesar pada medium korosif $\mathrm{NaCl} 3 \%$ dan $\mathrm{H}_{2} \mathrm{SO}_{4} 3 \%$ adalah pada konsentrasi inhibitor $0 \%$, yaitu sebesar $0,06 \times 10^{4} \mathrm{~mm} / \mathrm{y}$ dan $16,55 \times 10^{4} \mathrm{~mm} / \mathrm{y}$. Sementara, laju korosi terendah yaitu pada konsentrasi inhibitor $0,8 \%$ untuk medium korosif $\mathrm{NaCl} 3 \%$ dan $0,5 \%$ untuk medium korosif $\mathrm{H}_{2} \mathrm{SO}_{4} 3 \%$. Sehingga efektivitas korosi yang paling besar terjadi pada konsentrasi $0,8 \%$ pada medium korosif $\mathrm{NaCl} 3 \%$ dengan efektivitas sebesar85,71\%, dan 0,5\% pada medium korosif $\mathrm{H}_{2} \mathrm{SO}_{4} 3 \%$ dengan efektivitas sebesar 79,35\%. Hasil karakterisasi X-RayDiffraction (XRD) memperlihatkan bahwa fasa yang terbentuk adalah Fe murni. Karakterisasi Scanning Electron Microscopy (SEM) memperlihatkan cluster (gumpulan) tidak merata dan ukuran lebih kecil, lubang (hole) dan retakan (crack) juga lebih sedikit dengan inhibitor $0,8 \%$ untuk medium korosif $\mathrm{NaCl} 3 \%$ dan $0,5 \%$ untuk medium korosif $\mathrm{H}_{2} \mathrm{SO}_{4} 3 \%$ dibandingkan dengan inhibitor $0 \%$ ekstrak kulit buah maja pada medium korosif $\mathrm{NaCl} 3 \%$ dan $\mathrm{H}_{2} \mathrm{SO}_{4} 3 \%$. Karakterisasi Energy Dispersive Spectroscopy (EDS) pada sampel dengan medium korosif $\mathrm{H}_{2} \mathrm{SO}_{4} 3 \%$ didapatkan unsur $\mathrm{S}$ (Sulfat).

Kata kunci: Baja karbon API 5L, ekstrak kulit buah maja, inhibitor korosi, $\mathrm{NaCl}$, dan $\mathrm{H}_{2} \mathrm{SO}_{4}$. 


\section{PENDAHULUAN}

Korosi adalah suatu proses degradasi material atau hilangnya suatu material baik secara kualitas maupun kuantitas akibat adanya proses reaksi kimia dengan lingkungannya. Lingkungannya dapat berupa air, udara, larutan, tanah, dan biologikal yang sering disebut sebagai media korosif. Secara termodinamika peristiwa korosi terjadi ketika lingkungannya memiliki potensial elektroda standar lebih positif dari suatu logam [1] . Korosi pada logam sangat dipengaruhi oleh lingkungan yang mengandung gas limbah (sulfur dioksida, sulfat, hidrogen sulfida, klorida), kandungan $\mathrm{O}, \mathrm{pH}$ larutan, temperatur, kelembaban, kecepatan alir, dan aktifitas mikroba [2].

Korosi merupakan masalah besar bagi bangunan dan peralatan yang menggunakan material dasar logam seperti gedung, jembatan, mesin, pipa, mobil, kapal, dan lain sebagainya [3]. Proses korosi merupakan fenomena alam yang tidak dapat dihentikan, namun dapat dicegah dengan banyak cara yaitu pelapisan pada permukaan logam dengan suatu lapisan tak tembus, seperti cat, penambahan inhibitor dan lain-lain. Sejauh ini, penambahan inhibitor merupakan salah satu cara yang paling efektif untuk mencegah korosi karena dalam penggunaannya memerlukan biaya relatif murah dan prosesnya sederhana [4] .

Inhibitor korosi merupakan zat atau bahan yang bila ditambahkan dalam konsentrasi kecil ke dalam medium korosif dapat menurunkan atau mencegah laju korosi logam [1] . Inhibitor korosi dapat didefenisikan sebagai suatu zat yang apabila ditambahkan ke dalam lingkungan akan menurunkan serangan korosi lingkungan terhadap logam. Umumnya inhibitor korosi berasal dari senyawasenyawa organik dan anorganik [5] . Penggunaan inhibitor dari senyawa anorganik seperti nitrit $\left(\mathrm{NO}_{2}\right)$, kromat $\left(\mathrm{CrO}_{4}\right)$, fosfat $\left(\mathrm{PO}_{4}\right)$ telah banyak digunakan. Tetapi penggunaan inhibitor tersebut tidak ramah lingkungan, karena dapat menyebabkan pencemaran pada lingkungan yang digunakan sebagai inhibitor, seperti pencemaran pada air laut jika inhibitor digunakan pada baja perkapalan seperti baja API 5L [6].

Inhibitor organik yaitu inhibitor yang berasal dari bagian tumbuhan yang mengandung tanin, karena merupakan zat kimia mengandung atom $\mathrm{N}, \mathrm{O}, \mathrm{P}, \mathrm{S}$ dan atom-atomyang memiliki pasangan elektron bebas yang dapat berfungsi sebagai ligan yang akanmembentuk senyawa kompleks dengan logam [4]. Tanin biasanya terdapat pada daun, akar, kulit, buah dan batang tumbuhan [7].

Salah satu bahan alam yang banyak mengandung tanin dan berpotensi digunakan sebagai inhibitor korosi adalah kulit buah maja. Selain harganya yang murah dan jumlahnya yang berlimpah di Indonesia, banyaknya kandungan tanin pada daun gambir ini membuatnya berpotensi digunakan untuk menghambat laju korosi pada logam.Kadar tanin pada kulit buah maja mencapai 20\% [8] .

Penelitian tentang inhibitor korosi dilakukan oleh [9], pada penelitian ini menjelaskan tentang pengendalian laju korosi pada baja ringan dengan menggunakan inhibitor ekstrak kulit buah maja, dengan media air laut. Pada proses penelitian kulit buah maja diekstrak dengan metode maserasi dan untuk laju korosi dihitung dengan metode kehilangan berat, kemudian perendaman dilakukan selama 5, $15,25,35$ dan 45 hari dengan konsentrasi inhibitor $0 \%, 0,1 \%, 0,2 \%, 0,3 \%$ dan $0,4 \%$. Dari hasil penelitian didapatkan hasil efisiensi laju korosi pada konsentrasi inhibitor sebesar $0,4 \%$ dengan efektivitas sebesar 80,46\% dan waktu perendaman optimum selama 35 hari. 
Pada penelitian kali ini, baja yang digunakan adalah baja karbon sedang yang dipakai pada industri penghasil minyak bumi dan gas yaitu baja karbon API 5L. Baja karbon API 5L direndam dalam medium korosi $\mathrm{NaCl} 3 \%$ dan $\mathrm{H}_{2} \mathrm{SO}_{4} 3 \%$ dengan konsentrasi inhibitor yang digunakan sebesar $0 \%, 0,4 \%, 0,5 \%, 0,6 \%$, $0,7 \%$, dan $0,8 \%$ dengan lama perendaman selama 35 hari. Sampel baja hasil korosi akan dikarakterisasi dengan XRD (X-Ray Diffraction) untuk melihat fasa pada baja, SEM (Scanning Electron Microscopy) untuk melihat struktur mikro, dan EDS (Energy Dispersive Spectroscopy) untuk melihat produk-produk korosi yang terjadi dan menentukan laju korosi menggunakan metode kehilangan berat.

\section{METODE PENELITIAN}

Penelitian ini dimulai dengan pengambilan kulit buah maja sebanyak 300 gram dan dikeringkan dalam suhu ruang selama 30 hari untuk menghilangkan kadar air, kemudian di haluskan dan diekstraksi dengan etanol $70 \%$. Hasil ekstraksi disaring dan filtrat diuapkan menggunakan alat penguap putar vakum (rotary evaporator) dengan kecepatan $200 \mathrm{rpm}$ pada suhu $50^{\circ}$ hingga menghasilkan esktrak pekat. Selanjutnya baja yang sudah dipotong dengan ukuran panjang $10 \mathrm{~mm}$, lebar $10 \mathrm{~m}$, dan tinggi $5 \mathrm{~mm}$ dibersihkan dan ditimbang. Setelah itu, masuk dalam tahap pembuatan medium korosif $\mathrm{NaCl}$ dan $\mathrm{H}_{2} \mathrm{SO}_{4} 3 \%$. NaCl yang digunakan sebesar 3 gram ditambahkan aquabides sebanyak 100 ml. Selanjutnya, pembuatan larutan $\mathrm{H}_{2} \mathrm{SO}_{4}$ $3 \%$ yaitu $3 \quad \mathrm{ml}_{2} \mathrm{H}_{2} \mathrm{SO}_{4}$ ditambahkan aquabides $100 \mathrm{ml}$.

Setelah semuanya tersedia, maka masuk dalam tahap perendaman. Pada tahap ini baja yang sudah ditimbang dimasukkan dalam medium korosif $\mathrm{NaCl}$ $\mathrm{H}_{2} \mathrm{SO}_{4} 3 \%$ tanpa dan dengan inhibitor $0,4 \%, 0,5 \%, 0,65,0,7 \%$, dan $0,8 \%$. Jadi, ada 12 sampel pengujian. Perendaman sampel ditunjukkan pada Gambar 1.

Setelah direndam selama 35 hari sampel kemudian di bersihkan dan ditimbang kembali dan dilakukan karakterisasi XRD dan SEM-EDS Perhitungan rumus laju korosi dengan rumus:

$$
C R=\frac{K W}{A T \rho}
$$

Dengan $C R=$ Laju korosi $(\mathrm{mm} / \mathrm{y}), \quad K=$ Konstanta laju korosi, $W=$ Selisih massa (mg), $A=$ Luas permukaan $\left(\mathrm{mm}^{2}\right), T=$ Waktu perendaman(y), $\rho=$ Massa jenis $\left(\mathrm{mg} / \mathrm{mm}^{3}\right)$ sementara, untuk menghitung efisiensi menggunakan rumus:

$$
\eta(\%)=\frac{\left(C R_{\text {uninhibited }}-C R_{\text {inhibited }}\right)}{C R_{\text {uninhibited }}} \times 100
$$

Dimana $\eta=$ Efisiensi inhibitor (\%), $C R_{\text {uninhibited }}=$ Laju korosi tanpa inhibitor $(\mathrm{mm} / \mathrm{y}), C R_{\text {inhibited }}=$ Laju korosi dengan inhibitor $(\mathrm{mm} / \mathrm{y})$.
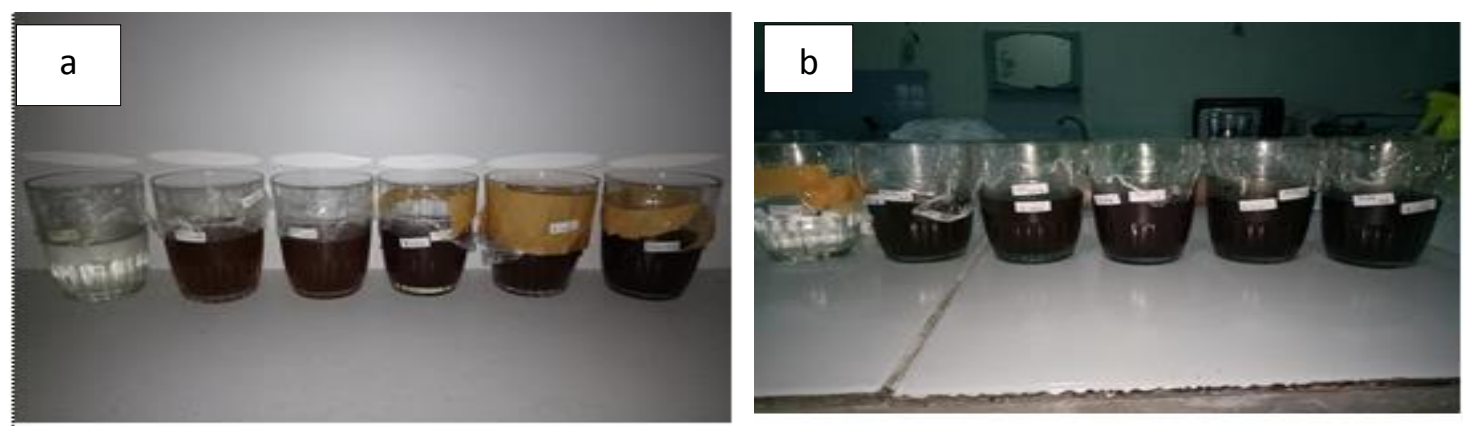

Gambar 1. Perendaman sampel (a) $\mathrm{NaCl} 3 \%$ (b) $\mathrm{H}_{2} \mathrm{SO}_{4} 3 \%$. 


\section{HASIL DAN PEMBAHASAN}

\section{Hasil Perhitungan Laju Korosi}

Hasil perhitungan laju korosi API 5L dalam lingkungan $\mathrm{NaCl} 3 \%$ danH $\mathrm{H}_{2} \mathrm{SO}_{4} 3 \%$ tanpa dan dengan inhibitor ekstrak kulit buah maja(Aegle Marmelos (L.) Corea) pada perendaman selama 35 hari ditunjukkan pada Gambar 2 dan 3 . Gambar 2 menunjukkan hubungan laju korosi dengan konsentrasi inhibitor ekstrak kulit buah maja (Aegle Marmelos (L.) Corea) dalam medium korosif $\mathrm{NaCl}$. Pada medium korosif $\mathrm{NaCl}$ penambahan inhibitor ekstrak kulit buah maja0\%, 0,4\% terjadi penurunan laju korosi dari 0,42 x $10^{4}$ $\mathrm{mm} / \mathrm{y}$ menjadi $0,08 \times 10^{4} \mathrm{~mm} / \mathrm{y}$,

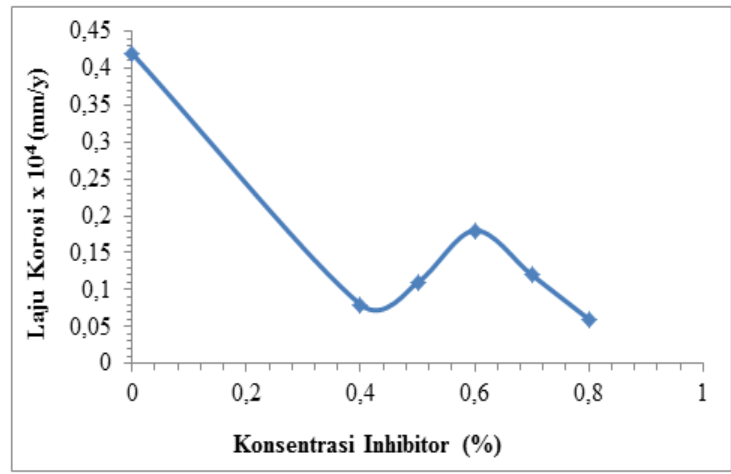

Gambar 2. Laju korosi baja API 5L dengan konsentrasi inhibitor dalam medium korosif $\mathrm{NaCl}$

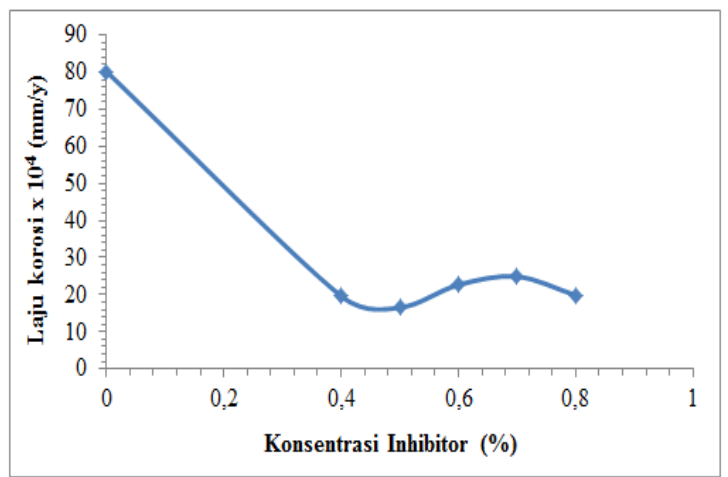

Gambar 3. Laju korosi baja API 5L dengan konsentrasi inhibitor dalam medium korosif $\mathrm{H}_{2} \mathrm{SO}_{4}$ ketika ditambahkan inhibitor pada konsentrasi $0,5 \%, \quad 0,6 \%$ laju korosi mengalami peningkatan dari $0,11 \times 10^{4}$ $\mathrm{mm} / \mathrm{y}$ menjadi $0,18 \times 10^{4} \mathrm{~mm} / \mathrm{y}$. Kemudian ketika ditambahkan inhibitor $0,7 \%, 0,8 \%$ laju korosi mengalami penurunan kembali dari $0,12 \times 10^{4} \mathrm{~mm} / \mathrm{y}$ menjadi $0,06 \times 10^{4}$ $\mathrm{mm} / \mathrm{y}$. Berdasarkan Gambar 2 didapatkan nilai laju korosi terendah pada konsentrasi $0,8 \%$ yaitu sebesar $0,06 \times 10^{4} \mathrm{~mm} / \mathrm{y}$.

Selanjutnya grafik hubungan laju korosi dengan konsentrasi inhibitor pada medium $\mathrm{H}_{2} \mathrm{SO}_{4}$ ditunjukkan pada Gambar 3 . Gambar 3 menunjukkan hubungan laju korosi dengan konsentrasi inhibitor ekstrak kulit buah maja (Aegle Marmelos (L.) Corea) dalam medium korosif $\mathrm{H}_{2} \mathrm{SO}_{4}$.Pada medium korosif $\mathrm{H}_{2} \mathrm{SO}_{4}$ penambahan inhibitor ekstrak kulit buah maja terjadi kenaikan dan penurunan nilai laju korosi dari setiap konsentrasi yang digunakan. Dimana pada konsentrasi $0 \%, 0,4 \%, 0,5 \%$ terjadi penurunan laju koroai. Tetapi terjadi kenaikan nilai laju korosi kembali pada konsentrasi $0,6 \%$, dan $07 \%$. Ketika ditambahkan inhibitor $0,8 \%$ laju korosi mengalami penurunan kembali. Berdasarkan Gambar tersebut didapatkan laju korosi terendah pada konsentrasi $0,5 \%$ sebesar $16,55 \times 10^{4} \mathrm{~mm} / \mathrm{y}$.

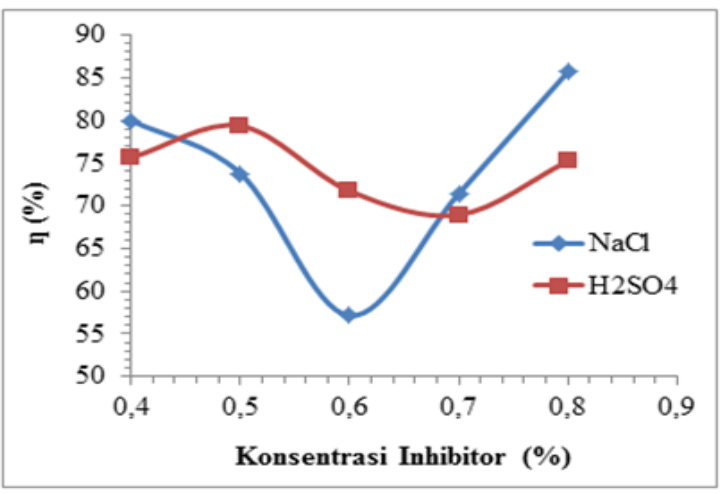

Gambar 4. Grafik hubungan konsentrasi inhibitor dengan efisiensi inhibitor ekstrak kulit buah maja pada medium $\mathrm{NaCl}$ danH $\mathrm{H}_{2} \mathrm{SO}_{4}$. 
Gambar 4 menunjukkan grafik hubungan antara konsentrasi inhibitor ekstrak kulit buah maja (Aegle Marmelos (L.) Corea) dengan efisiensi bahwa efisiensi inhibisi pada lingkungan $\mathrm{NaCl}$ dengan konsnetrasi $0,4 \%, 0,5 \%, 0,6 \%$, $0,7 \%$, dan $0,8 \%$ masing-masing sebesar $80 \%, 73,8 \%, 57,14 \%, 71,43 \%$, dan $85,71 \%$. Efisiensi terbesar pada medium korosif $\mathrm{NaCl}$ adalah pada saat konsentrasi $0,8 \%$ yaitu sebesar $85,71 \%$. Sedangkan efisiensi inhibisi pada medium $\mathrm{H}_{2} \mathrm{SO}_{4}$ dengan konsentrasi $0,4 \$, 0,5 \%, 0,6 \%, 0,7 \%$, dan $0,8 \%$ masing-masing sebesar $75,65 \%$, $79,35 \%, 71,73 \%, 68,95 \%$, dan $75,24 \%$. Dimana efisiensi terbesar pada medium korosif $\mathrm{H}_{2} \mathrm{SO}_{4}$ yaitu pada konsentrasi inhibitor $0,5 \%$ sebesar 79,35\%. Dari kedua medium ini, nilai efisiensi terbaik pada medium $\mathrm{NaCl}$, dikarenakan pada medium $\mathrm{NaCl}$ laju korosi lebih rendah dibandingkan pada medium $\mathrm{H}_{2} \mathrm{SO}_{4}$. Sehingga jika laju korosi semakin rendah maka efisensi semakin tinggi.

\section{Analisi XRD (X-Ray Diffraction)}

Dari hasil penelitian ketiga sampel yang telah diuji dicocokkan dengan PCPDFWIN versi 1.3 JCPSD-ICOD 1997 dengan nomor 06-0696 menunjukkan bahwa fasa yang terbentuk merupakan $\mathrm{Fe}$ murni dengan bidang 110, 200, dan 211 dengan simbol space group $1 \mathrm{~m} 3 \mathrm{~m}$ (229) dimana parameter sel $\mathrm{a}=\mathrm{b}=\mathrm{c}=2.866$, sudut kisinya $\alpha=\beta=\gamma=90^{\circ}$ dan hal ini mengidentifikasikan bahwa fasa $\mathrm{Fe}$ memiliki struktur kristal BCC (Body Center Cubic) untuk hasil XRD pada sampel $\mathrm{NaCl}$ $0 \%$ dan $0,8 \%$ dan untuk sampel $\mathrm{H}_{2} \mathrm{SO}_{4}$ $0,5 \%$

Penelitian terkait telah dilakukan [6]. yang melaporkan bahwa baja karbon rendah menghasilkan fasa Fe dengan bidang yang sama yaitu 110, 200, dan 211 dengan struktur kristal BCC (Body Center Cubic).

Untuk sampel $\mathrm{H}_{2} \mathrm{SO}_{4} 0 \%$ menunjukkan bahwa fasa yang terebentuk merupakan fasa amorf., hal ini dikarenakan pada sampl ini baja telah tertutupi oleh korosi sehingga tidak terlihat lagi fasa Fe.Difragtogram hasil XRD ditunjukkan pada Gambar 5 dan Gambar 6.

\section{Analisis SEM-EDS}

Hasil analisis SEM pada kedua sampel pada medium korosif $\mathrm{NaCl} 3 \%$ ditunjukkan pada Gambar 7.

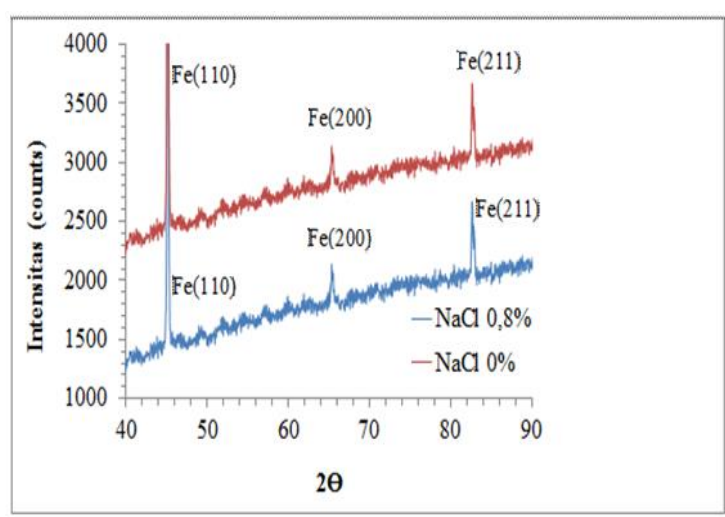

Gambar 5. Difragtogram tanpa dan dengan inhibitor0,8\% medium $\mathrm{NaCl}$.

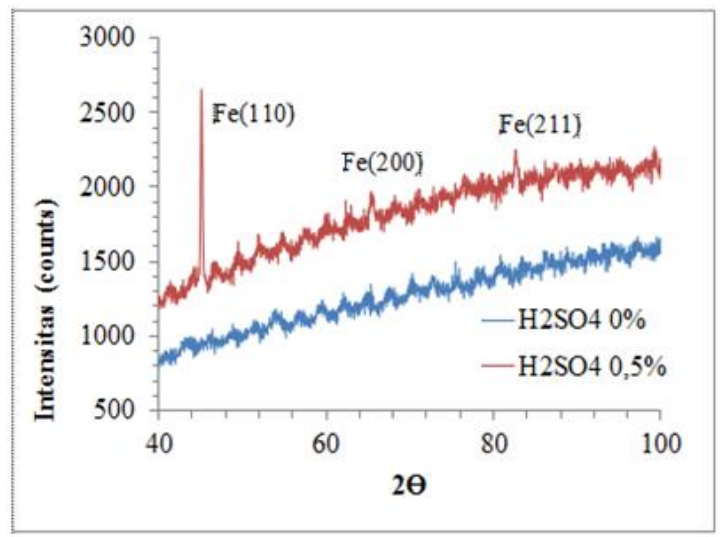

Gambar 6. Difragtogram tanpa dan dengan inhibitor0,5\% medium $\mathrm{H}_{2} \mathrm{SO}_{4}$. 

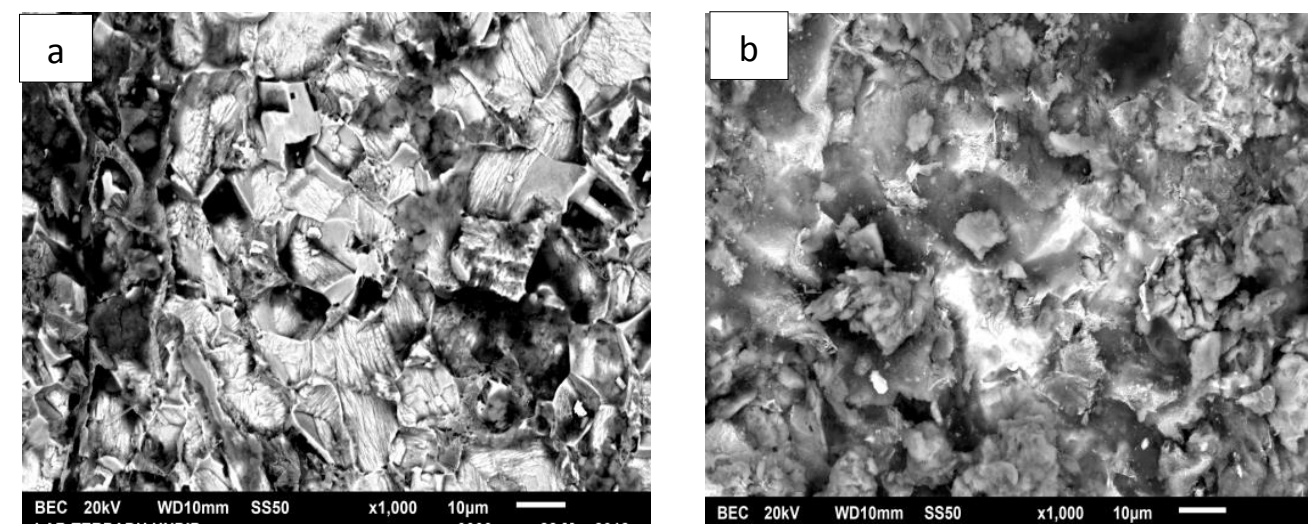

Gambar 7. Hasil SEM baja karbon API 5L pada medium korosif $\mathrm{NaCl}$ dengan (a) inhibitor 0\% dan (b) inhibitor $0,8 \%$

Berdasarkan hasil pengamatan dari Gambar 7(a) dan 7(b) terlihat dengan jelas adanya gumpalan (cluster) dengan ukuran yang bervariasi tersebar hampir pada semua permukaan setelah direndam dengan medium korosif $\mathrm{NaCl}$ tanpa menggunakan inhibitor. Gumpalan-gumpalan yang terbentuk menunjukan produk korosi yang diakibatkan reaksi antara ion $\mathrm{Cl}^{-}$dan ionion logam yang terdapat pada baja. Selain itu terlihat lubang (hole) pada permukaan baja yang tidak terlalu banyak. Lubang merupakan faktor utama penyebab terjadinya korosi pada suatu logam, karena merupakan jalan masuknya oksigen. Menurut [10], elektron-elektron yang terdapat pada logam akan bereaksi dengan oksigen, sehingga sampel akan kekurangan elektron dan terkorosi. Sedangkan pada Gambar 7(b) yang merupakan sampel dengan konsentrasi inhibitor $0,8 \%$ terlihat adanya retakan pada gumpalan, itu menandakan adanya korosi retak tegangan yang terbentuk. Proses peretakan pada korosi retak tegangan sangat dipengaruhi oleh lubang. Sebuah lubang kecil pada permukaan logam dapat berfungsi sebagai penyebab retakan.
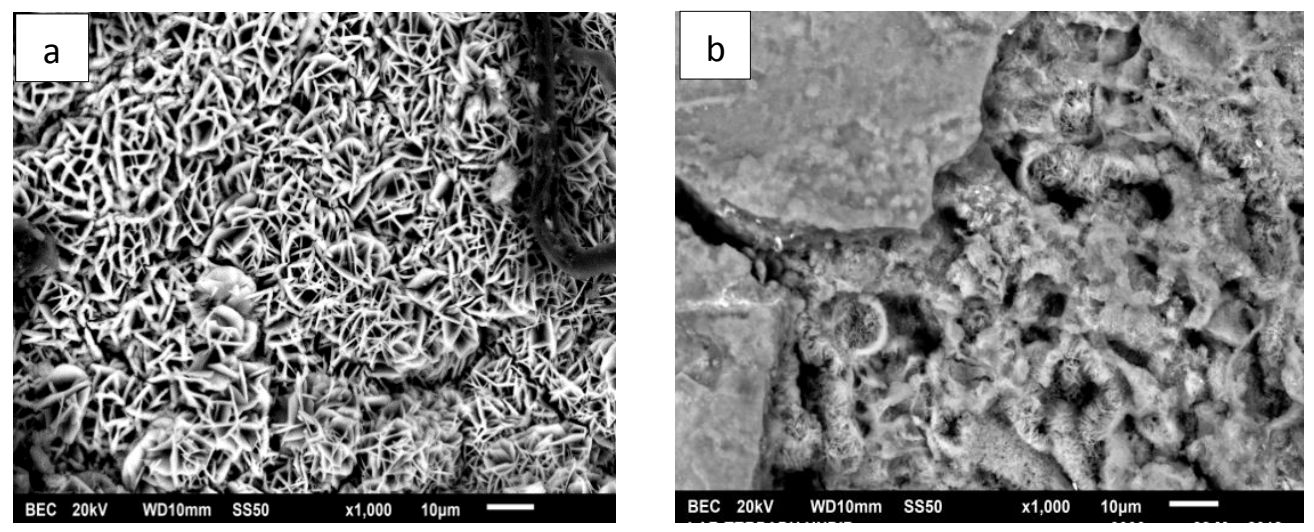

Gambar 8. Hasil SEM baja karbon API 5L pada medium korosif $\mathrm{H}_{2} \mathrm{SO}_{4}$ (a) tanpa inhibitor dan (b) dengan inhibitor $0,5 \%$ 
Berdasarkan hasil pengamatan dari Gambar 8(a) terlihat seluruh permukaan telah mengalami kerusakan dan ditutupi oleh lubang (hole) pada seluruh permukaan, selain itu terlihat adanya retakan yang menunjukan adanya korosi retak tenggang.Terlihat juga gumpalan-gumpalan pada permukaan baja yang menunjukan adanya produk korosi yang terbentuk. Sedangkan pada Gambar 8(b) setelah ditambahkan inhibitor terlihat bahwa pada permukaan baja terbentuk gumpalan yang tidak menutupi seluruh permukaan baja, dan terlihat lubang (hole) yang tidak tersebar merata pada permukaan baja. Selain itu terlihat adanya retakan yang besar pada sisi permukaan, hal ini menunjukan terjadinya korosi retak tenggan. Uji EDS dilakukan untuk melihat produk korosi yang tidak dapat dideteksi pada uji XRD. Hasil uji EDS pada sampel tanpa menggunakan inibitor dengan medium $\mathrm{NaCl}$ ditunjukkan pada Gambar 9.

Berdasarkan Gambar 9 baja kabron API 5L yang direndam dengan inhibitor $0 \%$ pada medium korosif $\mathrm{NaCl}$ memiliki 10 unsur yaitu $\mathrm{O}$ (oksigen), $\mathrm{Na}$ (natrium), $\mathrm{Al}$ (Aluminium), Si (Silikon), S (Sulfur), $\mathrm{Cl}$ (Clorida), Ca (kalsium), Cr (Cromium), $\mathrm{Fe}$ (besi), dan $\mathrm{Cu}$ (Cuprum). Unsur dengan persentasi terbesar ada pada Fe sebanyak $44,91 \%$ karena unsur utama dari baja merupakan $\mathrm{Fe}$, kemudian $\mathrm{O}$ (oksigen) sebanyak $14,55 \%$ menunjukkan telah terjadinya korosi pada logam. Selain itu terdeteksi unsur-unsur lain pengotor pada baja yang sangat sedikit jumlahnya yaitu $\mathrm{Na}$ (natrium) 0,24\%, Al (Aluminium) $0,27 \%$, Si (Silikon) 0,36\%, S (Sulfur) $0,22 \%, \mathrm{Cl}$ (Chlor) 0,11\%, Ca (Kalsium) $0,22 \%$, $\mathrm{Cr}$ () 0,76\%, dan $\mathrm{Cu}$ (Cuprum) $0,70 \%$.

Berdasarkan Gambar 10 bahwa baja karbon API 5L yang direndam dengan inhibitor $0,8 \%$ pada medium $\mathrm{NaCl} 3 \%$ memiliki 6 unsur yaitu O (oksigen), Al (Aluminium), Si (Silikon), P (Fosfor), $\mathrm{S}$ (Sulfur), V (Vanadium), dan Fe (besi). Unsur dengan persentasi terbesar ada pada Fe sebanyak 55,64\% karena unsur utama dari baja merupakan $\mathrm{Fe}$, kemudian $\mathrm{O}$ (oksigen) sebanyak $17,33 \%$ menunjukkan telah terjadinya korosi pada logam. Selain itu terdeteksi unsu-unsur lain atau pengotor pada baja atau inhibitor yang sangat sedikit jumlahnya yaitu $\mathrm{Al}$ (Aluminium) $0,32 \%, \mathrm{Si}$ (Silikon) 0,39\%, P (Fosfor) 0,24\%, S (Sulfur) 0,20\%, dan V (Vanadium) 0,06\% .

Berdasarkan Gambar 9 dan 10 dapat disimpulkan bahwa hasil EDS pada medium $\mathrm{NaCl}$ dengan konsentrasi 0,8\% korosi yang terjadi lebih sedikit dibandingkan hasil EDS pada medium $\mathrm{NaCl}$ dengan konnsentrasi $0 \%$. Hal ini dapat dilihat dari presentase $\mathrm{Fe}$ (besi) pada konsentrasi $0,8 \%$ lebih besar dibandingkan pada konsentrasi 0\%. Selanjutnya untuk hasil EDS dengan inhibitor $0 \%$ dengan medium $\mathrm{H}_{2} \mathrm{SO}_{4}$ ditunjukkan pada Gambar 11. 
Amilia Rasitiani, dkk.: Pengaruh Konsentrasi Ekstrak Kulit Buah Maja (Aegle Marmelos (L.) Corea) terhadap Laju Korosi Baja Karbon Api 5L pada Medium $\mathrm{NaCl} 3 \%$ dan $\mathrm{H}_{2} \mathrm{SO}_{4} 3 \%$

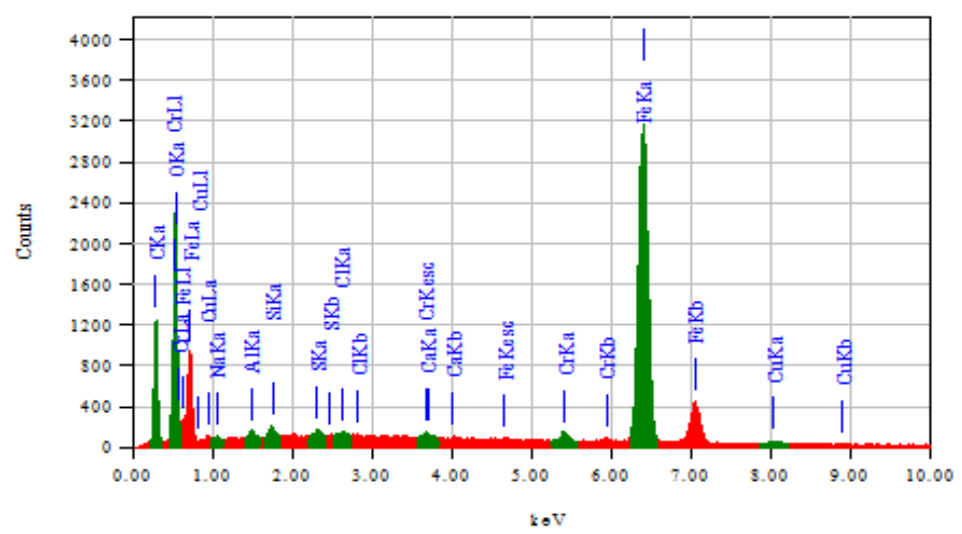

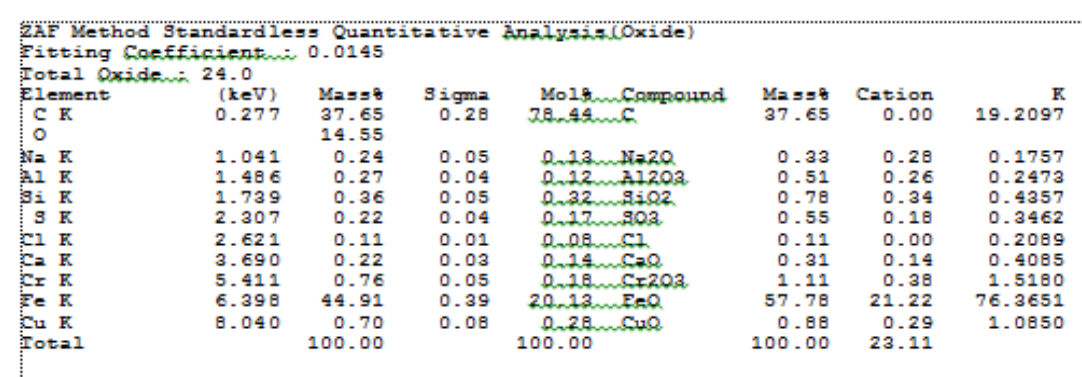

Gambar 9. Hasil EDS sampel tanpa menggunakan inhibitor pada medium korosif $\mathrm{NaCl}$

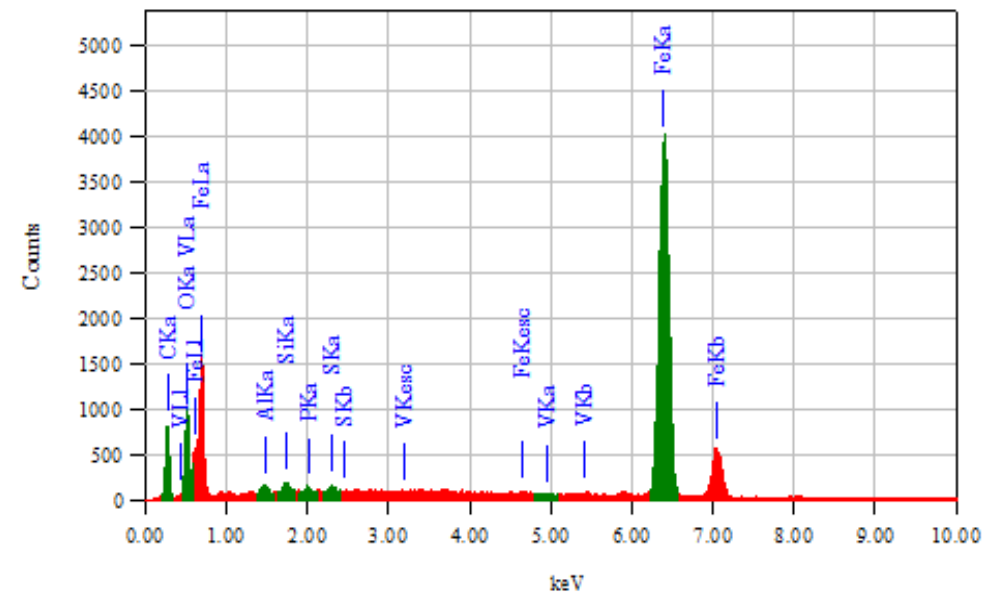

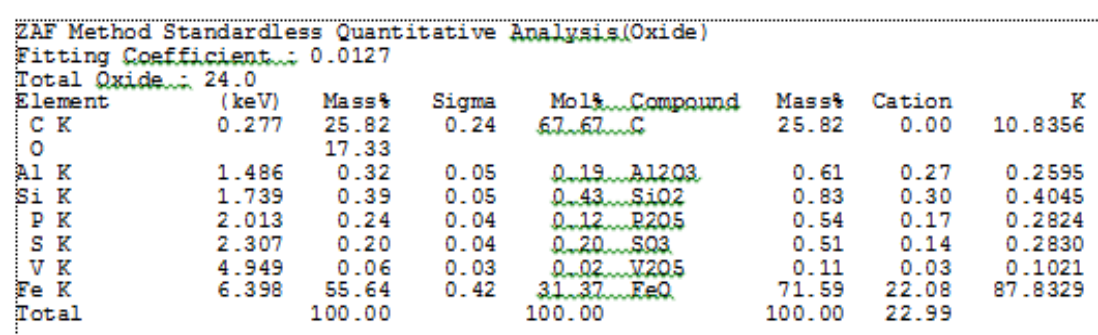

Gambar 10. Hasil EDS sampel dengan inhibitor 0,8\% pada medium korosif $\mathrm{NaCl}$ 


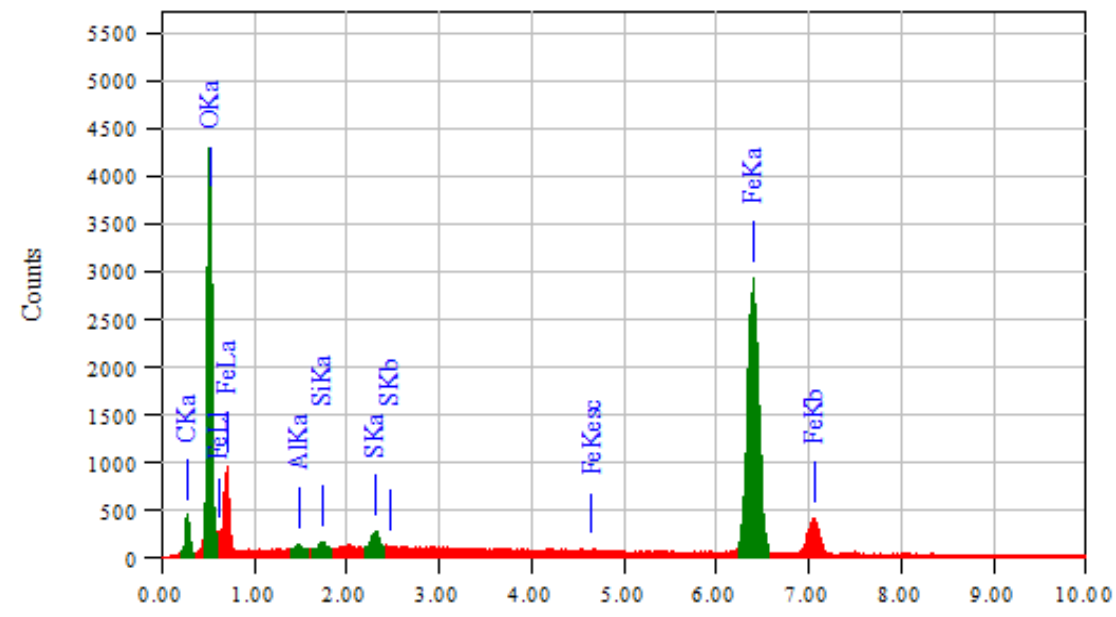

$\mathrm{keV}$

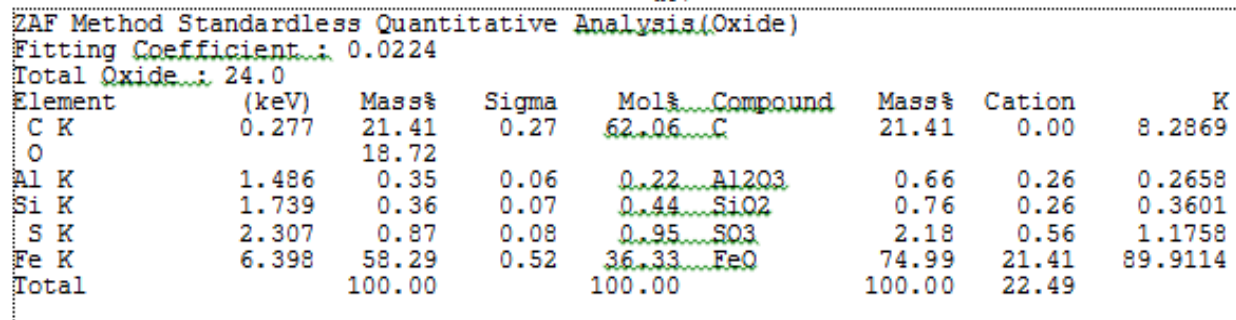

Gambar 11. Hasil EDS sampel tanpa inhibitor pada medium korosif $\mathrm{H}_{2} \mathrm{SO}_{4}$

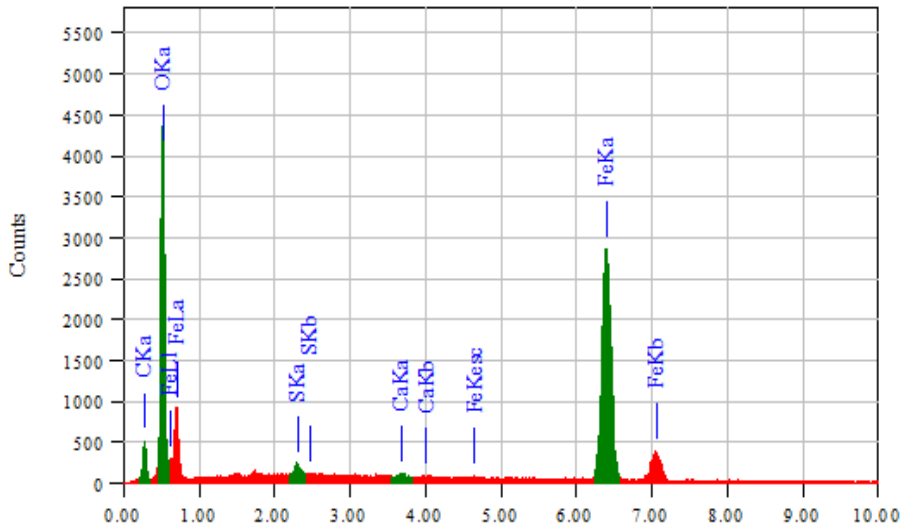

$\mathrm{keV}$

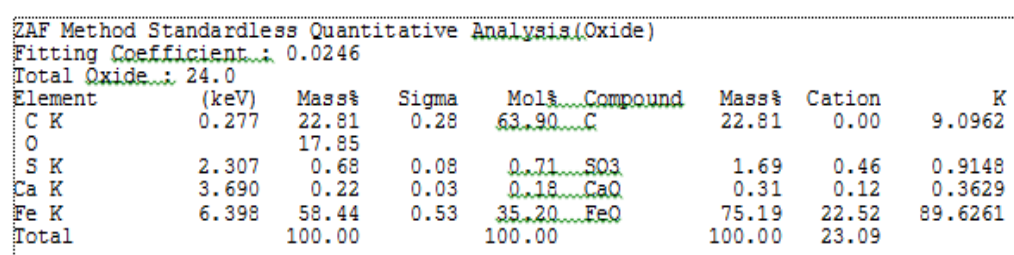

Gambar 12. Hasil EDS sampel dengan inhibitor $0,5 \%$ pada medium korosif $\mathrm{H}_{2} \mathrm{SO}_{4}$ 
Berdasarkan Gambar 11 bahwa baja karbon API 5L yang direndam tanpa inhibitor pada medium $\mathrm{H}_{2} \mathrm{SO}_{4} 3 \%$ memiliki 5 unsur yaitu $\mathrm{O}$ (oksigen), Al (Aluminium), $\mathrm{Si}$ (Silikon), S (Sulfur), dan Fe (besi). Unsur dengan persentasi terbesar ada pada Fe sebanyak 58,29\% karena unsur utama dari baja merupakan $\mathrm{Fe}$, kemudian $\mathrm{O}$ (oksigen) sebanyak $18,72 \%$ dan $\mathrm{S}$ (Sulfur) $0,87 \%$ karena penambahan Asam Sulfat $\left(\mathrm{H}_{2} \mathrm{SO}_{4}\right)$, terdeteksinya unsur $\mathrm{S}$ dan $\mathrm{O}$ menunjukkan telah terjadinya korosi pada logam. Selain itu terdeteksi unsur-unsur lain pengotor pada baja atau pada inhibitor yang sangat sedikit jumlahnya yaitu $\mathrm{Al}$ (Aluminium) $0,35 \%$, dan $\mathrm{Si}$ (Silikon) $0,36 \%$.

Selanjutnya hasil EDS dengan menggunakan inhibitor $0,5 \%$ pada medium korosif $\mathrm{H}_{2} \mathrm{SO}_{4}$ ditunjukkan pada Gambar 11. Berdasarkan Gambar 11 bahwa baja karbon API 5L yang direndam dengan inhibitor $0,5 \%$ pada medium $\mathrm{H}_{2} \mathrm{SO}_{4} 3 \%$ memiliki 4 unsur yaitu $\mathrm{O}$ (oksigen), $\mathrm{S}$ (Sulfur), Ca (kalsium), dan Fe (Besi). Unsur dengan persentasi terbesar ada pada $\mathrm{Fe}$ sebanyak 58,44\% karena unsur utama dari baja merupakan $\mathrm{Fe}$, kemudian $\mathrm{O}$ (oksigen) sebanyak $17,85 \%$ dan $\mathrm{S}$ (Sulfur) $0,68 \%$ karena penambahan asam Sulfat $\left(\mathrm{H}_{2} \mathrm{SO}_{4}\right)$ Terdeteksinya unsur $\mathrm{S}$ dan $\mathrm{O}$ menunjukkan telah terjadinya korosi pada logam. Selain itu terdeteksi unsur lain pengotor pada baja yang sedikit jumlahnya yaitu $\mathrm{Ca}$ (kalsium) $0,22 \%$.

\section{KESIMPULAN}

Efisiensi terbesar terdapat pada inhibitor $0,8 \%$ pada medium $\mathrm{NaCl}$ dan $0,5 \%$ pada medium $\mathrm{H}_{2} \mathrm{SO}_{4}$ dengan efisiensi masing-masing $85,71 \%$ dan $79,35 \%$. Hasil karakterisasi XRD memperlihatkan bahwa fasa yang terbentuk adalah $\mathrm{Fe}$ murni dengan bidang 110, 200, dan 211 pada hasil difragtogram sampel pada medium korosif $\mathrm{NaCl} 0 \%$ dan $0,8 \%$ dan pada medium korosif $\mathrm{H}_{2} \mathrm{SO}_{4} \quad 0,5 \%$, sedangkan pada medium korosif $\mathrm{H}_{2} \mathrm{SO}_{4}$ dengan konsentrasi inhibitor 0\% hasil XRD masih menujukan fasa amorf.

Hasil karakterisasi SEM menunjukkan mikro struktur permukaan baja pada sampel $\mathrm{NaCl}$ dengan konsentrasi $0,8 \%$ dan $\mathrm{H}_{2} \mathrm{SO}_{4}$ dengan konsentrasi $0,5 \%$ lebih sedikit terbentuk produk korosi dari pada permukaan baja pada sampel $\mathrm{NaCl}$ dan $\mathrm{H}_{2} \mathrm{SO}_{4}$ dengan konsentrasi inihibitor $0 \%$.

Hasil karakterisasi EDS pada sampel tanpa penambahan inhibitor didapatkan unsur $\mathrm{S}$ mengidentifikasi logam sudah terkontaminasi akibat interaksi antara asam sulfat dengan sampel pada medium korosif $\mathrm{H}_{2} \mathrm{SO}_{4}$.

Dari ketiga hasil karakterisasi dan perhitungan laju korosi didapatkan bahwa inhibitor ekstrak kulit buah maja efektif dalam menginhibisi laju korosi pada baja karbon API 5L dan dari kedua medium inhibitor ekstrak kulit buah maja lebih efektif pada medium $\mathrm{NaCl}$.

\section{DAFTAR PUSTAKA}

[1] J. Trethewey, K. R and Chamberlain, Korosi untuk Mahasiswa dan Rekayasa. 1991.

[2] Asdim, "penentuan Efisiensi Inhibisi Ekstrak Kulit Buah Manggis (Garcinia mangostana L) pada Reaksi Korosi Baja dalam Larutan Asam," J. Gradien, vol. 3, no. 2, pp. 273-276, 2007.

[3] H. P. Rieger, "Electrochemistry, Second Edition," in Chapman and Hall Inc, no. November, 1992, pp. 412-421.

[4] B. Ilim dan Hermawan, "Study Penggunaan Ekstrak Buah Lada, Buah Pinang dan Daun Teh Sebagai Inhibitor Korosi Baja Lunak dalam 
Air Laut Buatan Yang Jenuh Gas.," in Prosiding Seminar Nasional Sains dan Teknologi II, 2008, pp. 257-266.

[5]

A. M. Aidil, E. and Shams, "Corrosion Inhibition by Naturally Occurring substance-I. The Effect of Hibiscus Subdariffa (Karkade) Extract on the Dissolution of $\mathrm{Al}$ and Zn," Corros. Sci., vol. 12, no. 2, pp. 897-904, 1972.

[6] A. Bundjali, B., Surdia, N. M., Liang, Oei Ban., \& Bambang, "Pelarutan Besi Selektif pada Korosi Baja Karbon dalam Larutan Buffer Asetat, Natrium Bikarbonat-CO2 Jenuh," Sci. Technol., vol. 38A, pp. 149-161, 2006.

[7] Haryati, Potensi dan Peluang Tanaman Obat, Erlangga. Jakarta. pp. 23-28. 2008.

[8] S.K. Mehta, N., Chavda, A.M., Mujapara and P.P. Dodia, "Primary Identification of Certain Phytochemical Constituents of Aegle Marmelos (L.) Corr. Serr Responsile for Antimivrobial Activity Againts Selected Vegetable and Clinical Phatogen," Int. J. Phys. Soc. Sci., vol. 2, no. 6, pp. 140-147, 2012.

[9] S., Sumarji dan Hidayat, I. F., "Konsentrasi Ekstrak Kulit Buah Maja Terhadap Korosi Baja Karbon A53 dngan Media Air Laut," $J$. Rotor, vol. 9, no. 1, pp. 24-28, 2016.

[10] V. L. H. Vlack, Ilmu dan Teknologi Bahan (Ilmu Logam dan Bukan Logam). 1994. 
Amilia Rasitiani, dkk.: Pengaruh Konsentrasi Ekstrak Kulit Buah Maja (Aegle Marmelos (L.) Corea) terhadap Laju Korosi Baja Karbon Api 5L pada Medium NaCl 3\% dan $\mathrm{H}_{2} \mathrm{SO}_{4} 3 \%$ 